\title{
Contribution of Serotonin 3A Receptor to Motor Function and Its Expression in the Gastrointestinal Tract
}

\author{
Satoshi Aikiyo ${ }^{a}$ Kazuhisa Kishi ${ }^{a}$ Noriyuki Kaji ${ }^{a}$ b Shoma Mikawac \\ Makoto Kondo $^{d}$ Shoichi Shimada ${ }^{d}$ Masatoshi Hori ${ }^{a}$ \\ aDepartment of Veterinary Pharmacology, Graduate School of Agriculture and Life Sciences, University of \\ Tokyo, Tokyo, Japan; 'baboratory of Veterinary Pharmacology, School of Veterinary Medicine, Azabu University, \\ Kanagawa, Japan; 'Laboratory of Veterinary Clinical Pathology, Faculty of Veterinary Medicine, Okayama \\ University of Science, Ehime, Japan; dDepartment of Neuroscience and Cell Biology, Graduate School of Medicine, \\ Osaka University, Osaka, Japan
}

\section{Keywords}

Serotonin 3 A receptor $\cdot$ Gastrointestinal motility

\begin{abstract}
Introduction: The serotonin $3 \mathrm{~A}$ receptor $\left(5-\mathrm{HT}_{3 \mathrm{~A}} \mathrm{R}\right)$ is involved in vomiting and gastrointestinal motility. However, it is not well understood the expression pattern of $5-\mathrm{HT}_{3 \mathrm{~A}} \mathrm{R}$ in the gut immunohistochemically and how much contribution of $5-\mathrm{HT}_{3 \mathrm{~A}} \mathrm{R}$ to upper or lower intestinal motility. Objectives: We investigated the contribution of $5-\mathrm{HT}_{3 \mathrm{~A}} \mathrm{R}$ to gastrointestinal motor function by using $5-\mathrm{HT}_{3 \mathrm{~A}} \mathrm{R}$ KO mice and sought to identify $5-\mathrm{HT}_{3 A} \mathrm{R}$-expressing cells via immunohistochemical staining using $5-\mathrm{HT}_{3 \mathrm{~A}} \mathrm{R}$-GFP reporter mice. Methods: The expression of $5-\mathrm{HT}_{3 \mathrm{~A}} \mathrm{R}$ was measured in each section of the gut through real-time PCR. The motor function of the stomach and colon was assessed via the ${ }^{13} \mathrm{C}-\mathrm{oc}-$ tanoic acid breath test and colonic bead expulsion test, respectively, using $5-\mathrm{HT}_{3 \mathrm{~A}} \mathrm{R}$ KO mice. $5-\mathrm{HT}_{3 \mathrm{~A}} \mathrm{R}$-expressing cells in the muscle layer of the gut were identified by immuno-
\end{abstract}

karger@karger.com www.karger.com/dig

Karger $\stackrel{\text { ' }}{5}$

BOPEN ACCESS
(C) 2020 The Author(s)

Published by S. Karger AG, Basel

This article is licensed under the Creative Commons AttributionNonCommercial-NoDerivatives 4.0 International License (CC BYNC-ND) (http://www.karger.com/Services/OpenAccessLicense) Usage and distribution for commercial purposes as well as any distribution of modified material requires written permission. histochemical staining using $5-\mathrm{HT}_{3 \mathrm{~A}} \mathrm{R}$-GFP reporter mice. Results: $5-\mathrm{HT}_{3 \mathrm{~A}} \mathrm{R}$ was expressed throughout the digestive tract, and $5-\mathrm{HT}_{3 \mathrm{~A}} \mathrm{R}$ expression in the stomach and lower digestive tract was higher than that in the other sections. Motor function in the stomach and colon was lower in $5-\mathrm{HT}_{3 \mathrm{~A}} \mathrm{R}$ $\mathrm{KO}$ mice than in WT mice. As a result of immunohistochemical staining using GFP reporter mice, cholinergic neurons and PDGFRa ${ }^{+}$cells were shown to express $5-\mathrm{HT}_{3 \mathrm{~A}} \mathrm{R}$. In contrast, $5-\mathrm{HT}_{3 \mathrm{~A}} \mathrm{R}$ indicated by GFP fluorescence was rarely detected in ICC and smooth muscle cells. Conclusions: These results show that $5-\mathrm{HT}_{3 \mathrm{~A}} \mathrm{R}$ is highly expressed in the stomach and large intestine and that the activation of $5-\mathrm{HT}_{3 \mathrm{~A}} \mathrm{R}$ accelerates gastric emptying and large intestine transit. Additionally, $5-\mathrm{HT}_{3 \mathrm{~A}} \mathrm{R}$ is highly expressed in cholinergic neurons and some interstitial cells, such as PDGFRa ${ }^{+}$cells.

(c) 2020 The Author(s)

Published by S. Karger AG, Basel

Satoshi Aikiyo and Kazuhisa Kishi contributed equally to this work.
Masatoshi Hori

Department of Veterinary Pharmacology

Graduate School of Agriculture and Life Sciences, University of Tokyo

1-1-1 Yayoi, Bunkyo-ku, Tokyo 113-8657 (Japan)

horimasa@g.ecc.u-tokyo.ac.jp 


\section{Introduction}

Serotonin (5-hydroxytriptamin; 5-HT) is an essential substance for the living body and mainly exists in the intestine, brain, and blood. 5-HT acts as a neurotransmitter or autacoid in vivo and plays important roles in central and peripheral nervous activity control [1], platelet aggregation [2], inflammation [3], etc. The intestinal tract contains enterochromaffin cells, and $>80 \%$ of 5 - $\mathrm{HT}$ in the living body exists in the intestinal tract [4].

The serotonin receptors (5-HTRs) constitute 7 subfamilies $\left(5-\mathrm{HT}_{1} \mathrm{R}\right.$ to $\left.5-\mathrm{HT}_{7} \mathrm{R}\right)$ with 14 subtypes [5]. $5-\mathrm{HT}_{3} \mathrm{R}$ is a pentameric ligand-gated cation channel that is permeable to sodium, potassium, and calcium and is distinct from the other 5-HTRs in that it is a GTP-binding protein-coupled receptor [6]. It is composed of 5 subunits $\left(5-\mathrm{HT}_{3 \mathrm{~A}} \mathrm{R}-5-\mathrm{HT}_{3 \mathrm{E}} \mathrm{R}\right)$, and the $5-\mathrm{HT}_{3 \mathrm{~A}} \mathrm{R}$ subunit is essential for the formation of a functional receptor [7]. 5- $\mathrm{HT}_{3 \mathrm{~A}} \mathrm{R}$ contributes not only to neurotransmission in the brain and spinal cord [8] and to vomiting expression [9] but also to the motor function of the intestine [10]. In a clinical setting, $5-\mathrm{HT}_{3 \mathrm{~A}} \mathrm{R}$ inhibitors such as ondansetron are used as antiemetics. This antiemetic action is thought to be primarily targeted in the central chemoreceptor trigger zone and $5-\mathrm{HT}_{3 \mathrm{~A}} \mathrm{R}$ in the peripheral sensory and vagus nerves $[11,12]$.

Gastrointestinal motility is a biological function that is involved in the digestion, absorption, and excretion of food. The obstruction of gastrointestinal motility causes anorexia and constipation and reduces quality of life. Smooth muscle cells and neurons are well-known cell groups constituting the gastrointestinal motion system. In recent years, in addition to these cell groups, it has been proposed that interstitial cells of Cajal (ICC), which are pacemaker cells in gastrointestinal motility, and plateletderived growth factor receptor- $\alpha$ positive interstitial cells (PDGFRa ${ }^{+}$cells), which are considered to carry out regulation in an inhibitory manner, are essential for normal gastrointestinal motility [13]. Normal gastrointestinal motility is maintained by the close coordination of these cells. It has been reported that $5-\mathrm{HT}_{3 \mathrm{~A}} \mathrm{R}$ in the intestinal tract is expressed in nerves [14, 15] and ICC [16], but it has also been suggested that some subtypes of ICC do not express $5-\mathrm{HT}_{3 \mathrm{~A}} \mathrm{R}$ [17]. To understand the involvement of $5-\mathrm{HT}_{3 \mathrm{~A}} \mathrm{R}$ in gastrointestinal motility, it is necessary to more accurately identify the cells expressing $5-\mathrm{HT}_{3 \mathrm{~A}} \mathrm{R}$.

Focusing on the lower digestive tract, there are many reports on the relationship between $5-\mathrm{HT}_{3 \mathrm{~A}} \mathrm{R}$ and colonic motility, because antiemetic drugs, such as alosetron (5- $\mathrm{HT}_{3 \mathrm{~A}} \mathrm{R}$ antagonist), potently reduce or block propul- sive colonic motor complexes (CMMCs) in the mouse colon [18]. The current theories suggest that $5-\mathrm{HT}_{3 \mathrm{~A}} \mathrm{R}$ is constitutively active and involved colonic motility in mice, but endogenous 5-HT does not directly contribute the motility [19]. In addition, in the upper gastrointestinal tract, it is not well understood contribution of 5-HT/5$\mathrm{HT}_{3 \mathrm{~A}} \mathrm{R}$ signaling for the motility.

Hence, a major aim of this study was to determine the functional role of $5-\mathrm{HT}_{3 \mathrm{~A}} \mathrm{R}$ in the gastrointestinal motor function in rodents using $5-\mathrm{HT}_{3 \mathrm{~A}} \mathrm{R}$ knockout $(\mathrm{KO})$ mice. In addition, we attempted to identify the cell group expressing $5-\mathrm{HT}_{3 \mathrm{~A}} \mathrm{R}$ in the intramural plexus of the gastrointestinal muscular layer that controls gastrointestinal motility by using a reporter mouse in which $5-\mathrm{HT}_{3 \mathrm{~A}} \mathrm{R}$ is labeled with green fluorescent protein (GFP).

\section{Methods}

\section{Animals}

All of the animal care and experimental procedures complied with the Guide for Animal Use and Care published by The University of Tokyo and were approved by the Institutional Review Board of The University of Tokyo (P17-091). WT mice with a C57BL/6J background (Shiraishi Experimental Animals, Saitama, Japan), 5-HT ${ }_{3 \mathrm{~A}} \mathrm{R}-\mathrm{GFP}$ TG mice (GFP mice) with a C57BL/6J background (Mutant Mouse Regional Resource Center), and $5-\mathrm{HT}_{3 \mathrm{~A}} \mathrm{R} \mathrm{KO}$ mice (KO mice) with a C57BL/6J background (Mutant Mouse Regional Resource Center) were housed under controlled conditions (male, 10-14 weeks of age, 12-h light-dark cycles). In this study, we used a total of 49 mice.

\section{Quantitative RT-PCR}

Total RNA was extracted from each section of the digestive tract by using TRI Reagent (Molecular Research Center, Cincinnati, OH, USA) according to the manufacturer's instructions. cDNA was prepared by reverse transcription from total RNA using ReverTra Ace (Toyobo, Osaka, Japan). The amplification of cDNA was performed using THUNDERBIRD SYBR qPCR Mix (Toyobo) and AriaMx Real-Time PCR (Agilent, Santa Clara, CA, USA). The sequences of the primers used for these assays were as follows:

- 5- $\mathrm{HT}_{3 \mathrm{~A}} \mathrm{R}$ forward 5' -AGTTTGTGGACGTGGGGAAG-3'

- $5-\mathrm{HT}_{3 \mathrm{~A}} \mathrm{R}$ reverse $5^{\prime}$-AGCTGGTGAAAGTCAGAGAGCA-3'

- 18 s forward $5^{\prime}$-GACTCAACACGGGAAACCTCAC- $3^{\prime}$

- 18 s reverse 5'-CACCCACGGAATCGAGAAAG-3'

The expression levels of each mRNA were calculated using the $\Delta \Delta \mathrm{Ct}$ method, with RNA18S as an internal control gene for normalization.

\section{${ }^{13}$ C-Octanoic Acid Breath Test}

Gastric emptying was evaluated by the ${ }^{13} \mathrm{C}$-octanoic acid breath test as previously reported [20]. The animals were fasted for 12-16 $\mathrm{h}$ and placed in a chamber that was large enough for the mice to move freely. After the administration of $200 \mathrm{mg}$ of a test meal consisting of heated egg yolk and $0.2 \mu \mathrm{L}^{13} \mathrm{C}$-octanoic acid (Cambridge Isotope Laboratories, Inc., Tewksbury, MA, USA), a blow pump device (Thermo Fisher Scientific, Tokyo, Japan) collected breath 
samples that had accumulated in the chamber at a flow rate of 70 $\mathrm{mL} \mathrm{min}^{-1}$ for a duration of $1 \mathrm{~min}$, and the samples were directed into a breath collection bag (Otsuka Pharmaceutical Co., Ltd., Tokyo, japan). After the administration of the test meal, breath samples were collected from both WT mice and 5- $\mathrm{HT}_{3 \mathrm{~A}} \mathrm{R} \mathrm{KO}$ mice (KO mice) every $10 \mathrm{~min}$ for the first $120 \mathrm{~min}$, after which breath collection was performed at 140,160, 180, 210 and 240 min after the administration of the test meal. The ${ }^{13} \mathrm{CO}_{2} /{ }^{12} \mathrm{CO}_{2}$ ratio in the breath samples was analyzed using an infrared spectroscopic analyzer (Otsuka Electronics Co., Ltd., Osaka, Japan), and changes in ${ }^{13} \mathrm{CO}_{2}\left(\Delta^{13} \mathrm{C}\right.$, \%o) were calculated from the ${ }^{13} \mathrm{CO}_{2} /{ }^{12} \mathrm{CO}_{2}$ ratio. Mixed gas composed of $5 \%{ }^{12} \mathrm{CO}_{2}$ and $95 \% \mathrm{O}_{2}$ was used as a standard. The maximum concentration $\left(C_{\max } ; \%\right)$, the time to reach the maximum concentration $\left(T_{\max } ; \min \right)$, and the area under the exhalation concentration-time curve (AUC $240 \mathrm{~min} ; \%$ min) were calculated using the $\Delta^{13} \mathrm{C}$ value. The half-life $\left(T_{1 / 2} ; \mathrm{min}\right)$ was calculated from the slope of the elimination phase in the $\Delta^{13} \mathrm{C}$ curve.

Colonic Bead Expulsion Test

A colonic bead expulsion test was performed to study colonic transit. Mice were anesthetized with isoflurane. Saline and atropine $\left(1 \mathrm{mg} \mathrm{kg}^{-1}\right)$ were administered subcutaneously $30 \mathrm{~min}$ before bead insertion. Plastic beads were inserted into the distal colon by using a probe. The diameter of the beads was $1.5 \mathrm{~mm}$. The propulsion distance of the beads was $3 \mathrm{~cm}$. After withdrawing the probe, the inhalation of isoflurane by the mice was stopped, and the mice were placed in individual cages. The time between when the mice woke up and the beads were expelled was measured. When the beads were expelled from the anus, the bead expulsion test was complete.

\section{Immunofluorescence}

The stomach and colon were isolated from the mice, and the luminal contents were flushed out. The samples were fixed in $4 \%$ paraformaldehyde in PBS at $4^{\circ} \mathrm{C}$ overnight, followed by successive immersion in 10, 20, and 30\% sucrose in PBS for $2 \mathrm{~h}$ each at room temperature. Then, they were frozen with the Tissue-Tek O.C.T. compound (Sakura Finetek Japan, Tokyo, Japan) in liquid nitrogen. The samples were cut into $10-\mu \mathrm{m}$-thick sections with a coldtome (Sakura Finetek Japan) and placed on MAS-coated glass slides (Matsunami Glass, Osaka, Japan). After washing with PBS, the tissues were permeabilized and blocked, followed by incubation with a rabbit anti-GFP antibody (1:500, A11122; Thermo Fisher Scientific), chicken anti-GFP antibody (1:500, ab13970; Abcam, Cambridge, UK), rabbit anti-protein gene product 9.5 (PGP9.5) antibody (1:250, ADI-905-520-1; Enzo Life Sciences, Farmingdale, NY, USA), goat anti-choline acetyltransferase antibody (1:200, AB144P, MERCK, Kenilworth, MA, USA), goat antiPDGFRa PE Conjugated (1:500, FAB1062P, R\&D, Minneapolis, $\mathrm{MN}$, USA), or rat anti-c-Kit antibody (Clone ACK4, 1:500, ab112177; Abcam) in blocking solution at $4^{\circ} \mathrm{C}$ overnight. After washing thoroughly, the samples were incubated with the following secondary antibodies: Alexa Fluor 488 donkey anti-rabbit IgG (1:500, A21206; Thermo Fisher Scientific), Alexa Fluor 488 goat anti-chicken IgG (1:500, A11039; Thermo Fisher Scientific), Alexa Fluor 594 goat anti-rat IgG (1:500, A11007; Thermo Fisher Scientific), Alexa Fluor 594 donkey anti-rabbit IgG (1:500, A21207; Thermo Fisher Scientific), and Alexa Fluor 594 donkey anti-goat IgG (1:500, A11058; Thermo Fisher Scientific) at room temperature for $1 \mathrm{~h}$. The sections were washed several times in TBS and counterstained with $1 \mu \mathrm{g} \mathrm{mL}^{-1}$ DAPI (MERCK), followed by mounting. Immunofluorescence was observed using an Eclipse Ti-E confocal microscope with EZ-C1 software (Nikon, Tokyo, Japan).

\section{Whole-Mount Pyloric Antrum and Colonal Muscularis}

All operations were performed in a shaded state. The tissue sheets were fixed in $10 \%$ neutral buffered formalin for $30 \mathrm{~min}$ at room temperature with the muscularis tissue sheets pinned to the silicon base of dishes. After fixation, the whole-mount preparations were washed 3 times in TBS for $30 \mathrm{~min}$. After $30 \mathrm{~min}$ of blocking with $2 \%$ BSA in TBS, the samples were stained with $1 \mu \mathrm{g} \mathrm{mL}$ DAPI (MERCK), followed by mounting. The samples were observed using an Eclipse Ti-E confocal microscope with EZ-C1 software (Nikon, Tokyo, Japan).

\section{Statistical Analysis}

The results are expressed as the means \pm SEM. All data were compared using Student's $t$ test for 2 groups. A value of $p<0.05$ was considered statistically significant.

\section{Results}

\section{Expression of $5-\mathrm{HT}_{3 A} \mathrm{R}$ in the Whole Digestive Tract}

To investigate the tendency of the expression of $5-\mathrm{HT}_{3 \mathrm{~A}} \mathrm{R}$ in the whole digestive tract, real-time PCR was conducted (Fig. 1). The results showed that the mRNA expression of $5-\mathrm{HT}_{3 \mathrm{~A}} \mathrm{R}$ presented a tendency to be high in the stomach and large intestine (esophagus: $4.64 \pm$ 3.75, gastric corpus: $4.96 \pm 2.47$, gastric fundus: $2.54 \pm$ 0.822 , pyloric antrum: $1.44 \pm 0.28$, duodenum: $1.59 \pm$ 0.44 , jejunum: $1.00 \pm 0.13$, ileum: $1.92 \pm 0.34$, cecum: 3.53 \pm 1.81 , proximal colon: $5.34 \pm 1.73$, distal colon: $8.67 \pm$ 2.35 , rectum: $12.40 \pm 5.09, n=3-6)$. These results led us to propose that $5-\mathrm{HT}_{3 \mathrm{~A}} \mathrm{R}$ is abundant in the stomach and large intestine. Therefore, we studied motor function mediated via $5-\mathrm{HT}_{3 \mathrm{~A}} \mathrm{R}$ in the stomach and large intestine.

\section{In vivo Gastric Emptying}

To assess the contributory effect of $5-\mathrm{HT}_{3 \mathrm{~A}} \mathrm{R}$ on gastric motility, gastric emptying was measured using the ${ }^{13} \mathrm{C}$ octanoic acid breath test (Fig. 2a). As gastric emptying was delayed, the values of $C_{\max }$ and $\mathrm{AUC}_{240 \mathrm{~min}}$ decreased, but $T_{\max }$ and $T_{1 / 2}$ increased. The results of the ${ }^{13} \mathrm{C}$-octanoic acid breath test showed that $T_{\max }$ was significantly increased in $\mathrm{KO}$ mice compared with WT mice (control $T_{\text {max }}: 96.67 \pm 8.39 \mathrm{~min} ; \mathrm{KO} T_{\max }: 168.57 \pm 5.51 \mathrm{~min}$; $* * * p<0.001$ WT vs. KO, $n=6-7$ ) (Fig. 2b).

In addition, for the other parameters, $C_{\max }, T_{1 / 2}$, and $\mathrm{AUC}_{240 \mathrm{~min}}$, there was an upward tendency of $T_{1 / 2}$ in $\mathrm{KO}$ mice compared with WT mice (control $C_{\max }: 34.77 \pm$ 


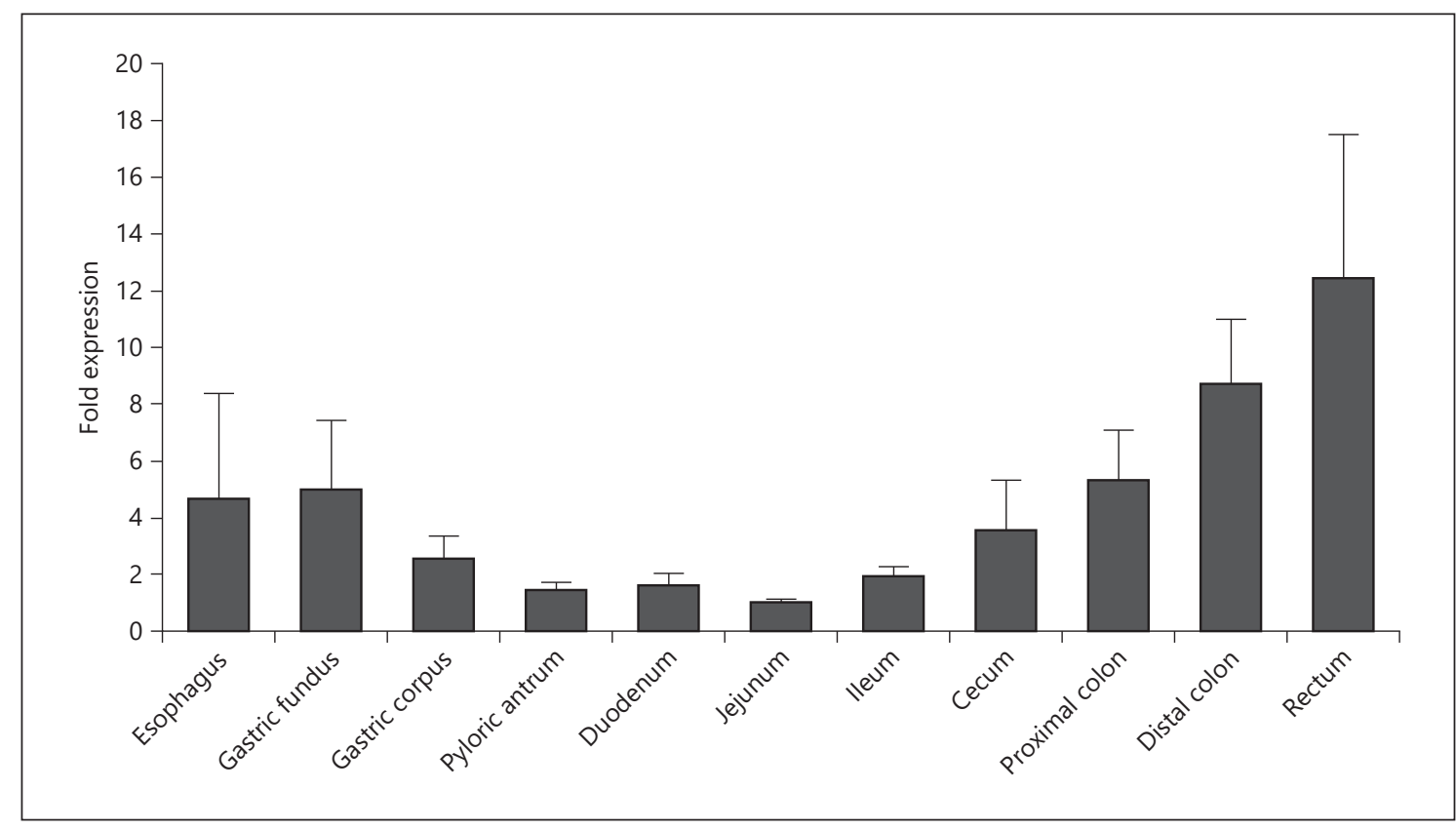

Fig. 1. Comparison of the relative mRNA expression of $5-\mathrm{HT}_{3 \mathrm{~A}} \mathrm{R}$ between each section of the digestive tract. The relative expression level of the $5-\mathrm{HT}_{3 \mathrm{~A}} \mathrm{R}$ gene was normalized to that of $18 \mathrm{~S} \mathrm{rRNA}$. The normalized expression levels were then converted to fold changes (vs. the jejunum). Each column shows the mean \pm SEM $(n=3-6)$.

$1.21 \%$ o, $T_{1 / 2}: 63.62 \pm 2.92 \mathrm{~min}, \mathrm{AUC}_{240 \mathrm{~min}}: 5,458.0 \pm$ $210.0 \%$ min; KO $C_{\max }: 30.49 \pm 1.61 \%$, $T_{1 / 2}: 193.72 \pm$ $55.71 \mathrm{~min}, \mathrm{AUC}_{240 \mathrm{~min}}: 5,390.2 \pm 304.6 \%$. $\mathrm{min}$; WT vs. $\mathrm{KO}, n=6-7$ ) (Fig. 2b). These results suggest that the activation of $5-\mathrm{HT}_{3 \mathrm{~A}} \mathrm{R}$ is involved in normal gastric emptying.

\section{In vivo Large Intestinal Motility}

To assess the contributory effect of $5-\mathrm{HT}_{3 \mathrm{~A}} \mathrm{R}$ on large intestinal motility, large intestinal motility in WT and KO mice was compared using the colonic bead expulsion test. As a positive control, the effect of atropine on colonic motility (WT-Atropine) was measured (Fig. 3a). The results showed that the bead expulsion time in the WTAtropine group was significantly increased compared with that in the WT-Saline group (WT-Saline: $203.8 \pm$ $10.14 \mathrm{~s}$, WT-Atropine: $842.0 \pm 28.65 \mathrm{~s},{ }^{* * *} p<0.001 \mathrm{WT}$ Saline vs. WT-Atropine, $n=5)$. Next, large intestinal motility in WT and KO mice was compared (Fig. 3b). The results showed that the bead expulsion time of the $\mathrm{KO}$ mice was significantly increased compared with that of the WT mice (WT: $230.6 \pm 17.61 \mathrm{~s}$, KO: $647.6 \pm 27.75 \mathrm{~s}$, ${ }^{* * *} p<0.001 \mathrm{WT}$ vs. KO, $\left.n=5\right)$. These results suggest that $5-\mathrm{HT}_{3 \mathrm{~A}} \mathrm{R}$ is involved in the maintenance of regular motor function in the large intestine.

Motor Function and Expression of 5-HT3AR

\section{Identification of 5-HT ${ }_{3 A} R$-Expressing Cells in the Muscular Layer}

To investigate which cells express $5-\mathrm{HT}_{3 \mathrm{~A}} \mathrm{R}$ in the muscular layer of the digestive tract, GFP mice were used for immunohistochemistry analysis of the pyloric antrum, which contributes to motor function in the stomach and colon. These results showed that there were some PGP9.5(+)/GFP(+) cells present in the pyloric antrum and colon (Fig. 4a-1). Moreover, the expression of $5-\mathrm{HT}_{3 \mathrm{~A}} \mathrm{R}$ in neurons was investigated using choline acetyltransferase (ChAT), which is a typical marker of cholinergic neurons (Fig. $4 \mathrm{~m}-\mathrm{x}$ ). These results showed that there were some ChAT $(+) / G F P(+)$ cells in the pyloric antrum and colon.

Because the motor function of the digestive tract is regulated by not only the nerves but also the crosstalk of ICC and PDGFRa ${ }^{+}$cells, immunohistochemistry analysis of ICC and PDGFRa $\alpha^{+}$cells was conducted. c-Kit $(+) / G F P(+)$ cells could not be found in the pyloric antrum or colon (Fig. 5). In contrast, some PDGFR $(++) / G F P(+)$ cells were found in the pyloric antrum and colon (Fig. 6). Additionally, whole mount samples of the antrum and colon were used to investigate whether $5-\mathrm{HT}_{3 \mathrm{~A}} \mathrm{R}$ was expressed in smooth muscle cells. Expression of $5-\mathrm{HT}_{3 \mathrm{~A}} \mathrm{R}$ was not confirmed in smooth muscle cells shown by DAPI (Fig. 7). 

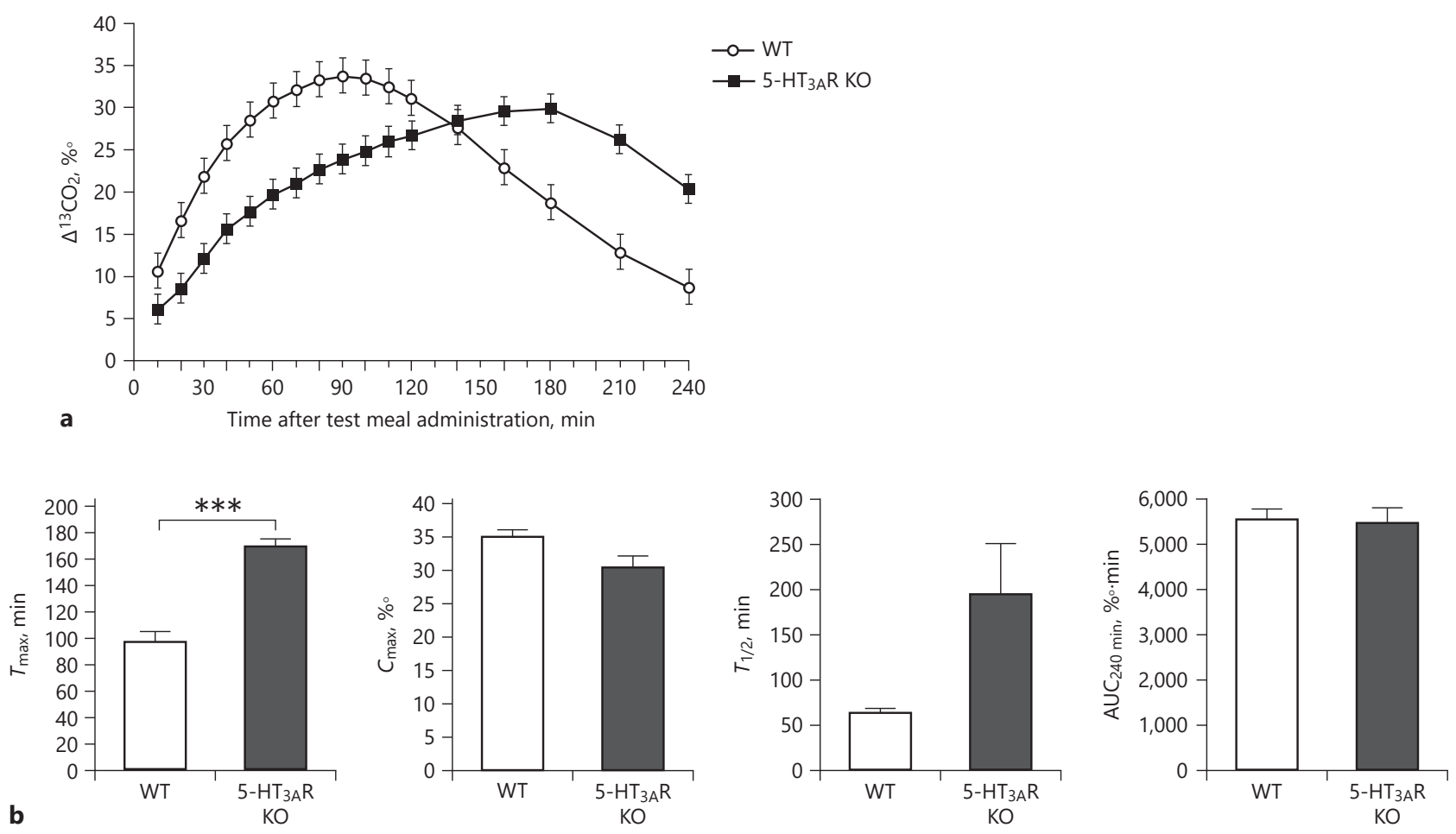

Fig. 2. Delayed gastric emptying resulting from the deficiency of $5-\mathrm{HT}_{3 \mathrm{~A}} \mathrm{R}$. a Time-course of gastric emptying measured by the ${ }^{13} \mathrm{C}$-octanoic acid breath test in WT mice and $5-\mathrm{HT}_{3 \mathrm{~A}} \mathrm{R} \mathrm{KO}$ mice. Each column shows the mean $\pm \operatorname{SEM}(n=6-7)$. b Quantification of $T_{\max }, C_{\max }, \mathrm{AUC}_{240 \mathrm{~min}}$, and $T_{1 / 2}$ calculated from (a). Each column shows the mean $\pm \operatorname{SEM}(n=6-7) .{ }^{* * *} p<0.001$; significantly different from the control.

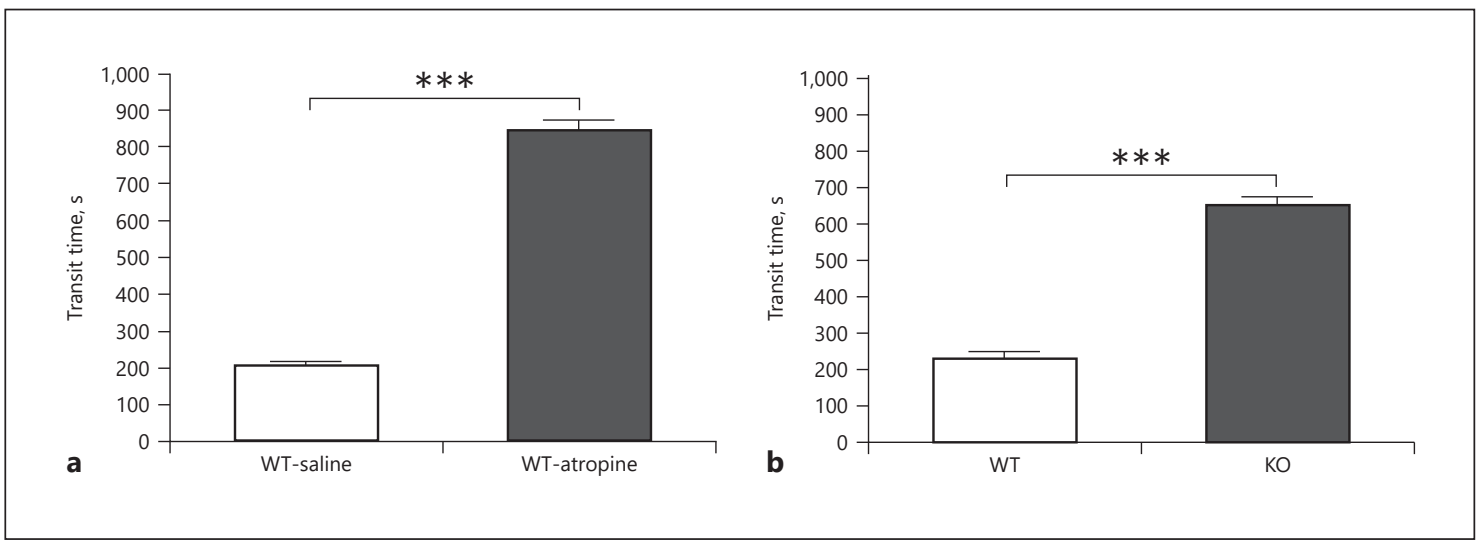

Fig. 3. Bead expulsion time was measured in WT mice and KO mice. Groups: WT-Saline group (WT mice administered saline) and WT-Atropine group (WT mice administered atropine) (a); WT group and KO group (b). Data are presented as the mean \pm SEM $(n=5) .{ }^{* * *} p<0.001$; significantly different from the control. 


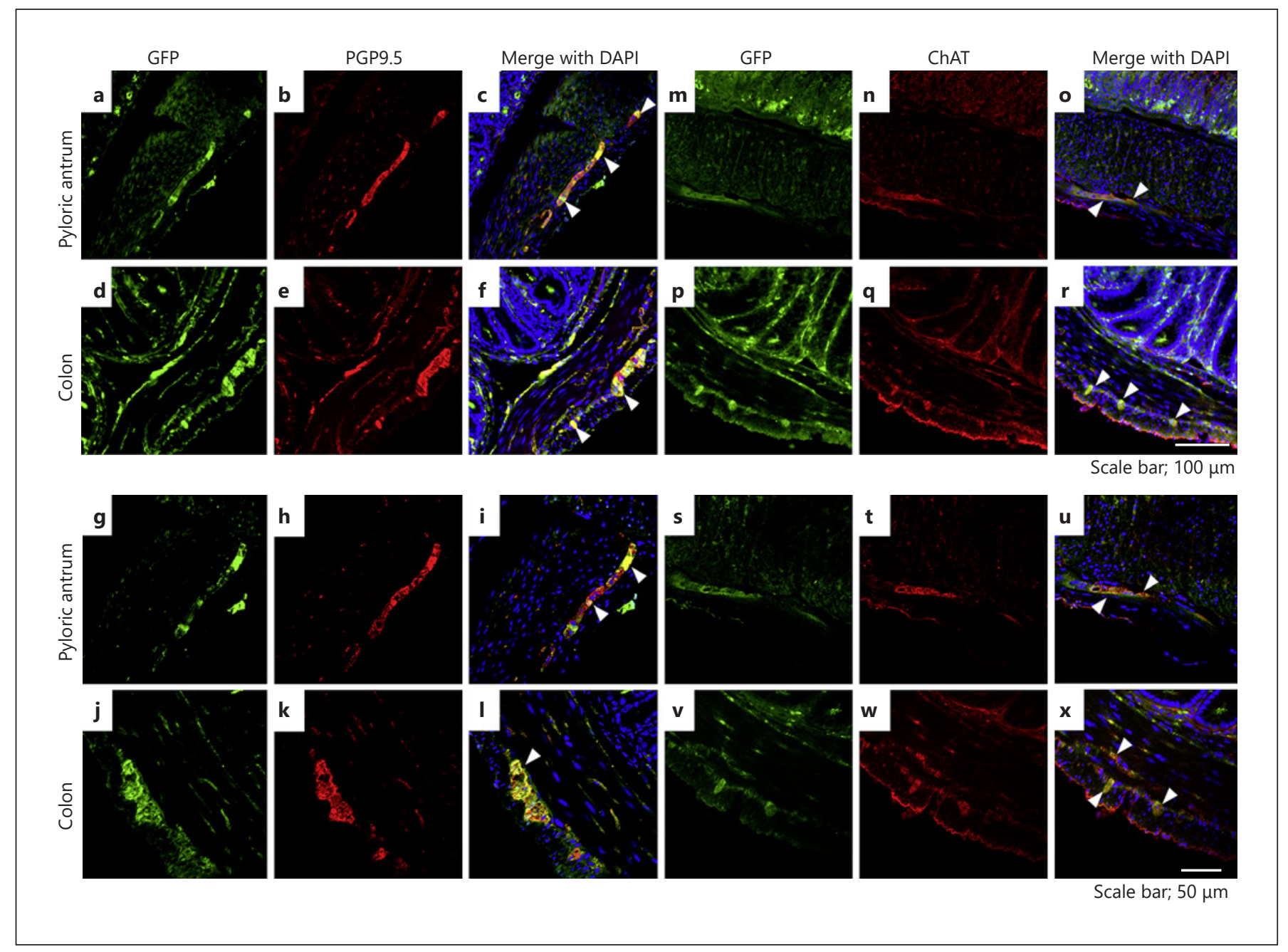

Fig. 4. Representative images of immunofluorescent staining for $5-\mathrm{HT}_{3 \mathrm{~A}} \mathrm{R}$ (green) and PGP9.5 (red) in the pyloric antrum $(\mathbf{a}-\mathbf{c}, \mathbf{g}-\mathbf{i})$ and colon $(\mathbf{d}-\mathbf{f}, \mathbf{j}-\mathbf{I})$ and for $5-\mathrm{HT}_{3 \mathrm{~A}} \mathrm{R}$ (green) and choline acetyltransferase (ChAT, red) in the pyloric antrum $(\mathbf{m}-\mathbf{o}, \mathbf{s}-\mathbf{u})$ and colon $(\mathbf{p}-\mathbf{r}, \mathbf{v}-\mathbf{x})$ of $5-\mathrm{HT}_{3 \mathrm{~A}} \mathrm{R}$ GFP mice. Merged images are a combination of green and red color images. Arrowheads indicate merged cells (yellow). Scale bars, $100 \mu \mathrm{m}(\mathbf{a}-\mathbf{f}, \mathbf{s}-\mathbf{x}), 50 \mu \mathrm{m}$ $(\mathbf{g}-\mathbf{I}, \mathbf{s}-\mathbf{x})$.

These results suggest that $5-\mathrm{HT}_{3 \mathrm{~A}} \mathrm{R}$ is expressed in cholinergic neurons and PDGFRa ${ }^{+}$cells.

\section{Discussion}

In this study, we analyzed the function of $5-\mathrm{HT}_{3 \mathrm{~A}} \mathrm{R}$ in the gastrointestinal tract and the cells expressing $5-\mathrm{HT}_{3 \mathrm{~A}} \mathrm{R}$ in the gastrointestinal muscle layer using $5-\mathrm{HT}_{3 \mathrm{~A}} \mathrm{R} \mathrm{KO}$ mice and $5-\mathrm{HT}_{3 \mathrm{~A}} \mathrm{R}$ GFP reporter mice, respectively. The results showed that $5-\mathrm{HT}_{3 \mathrm{~A}} \mathrm{R}$ is involved in motor function in the stomach and lower gastrointestinal tract. It was also revealed that $5-\mathrm{HT}_{3 \mathrm{~A}} \mathrm{R}$ is expressed in cholinergic nerves and PDGFRa ${ }^{+}$cells in the myenteric plexus responsible for gastrointestinal motility.

Thus far, the expression of $5-\mathrm{HT}_{3 \mathrm{~A}} \mathrm{R}$ in the gastrointestinal tract has been reported in the jejunum [21], colon [10], and rectum [15]. However, the differences in the expression levels of $5-\mathrm{HT}_{3 \mathrm{~A}} \mathrm{R}$ between each section of the digestive tract were unknown. In the current study, we found that $5-\mathrm{HT}_{3 \mathrm{~A}} \mathrm{R}$ mRNA expressions tended to be high in the stomach and lower in the gastrointestinal tract rather than the small intestine. The high mRNA expression of $5-\mathrm{HT}_{3 \mathrm{~A}} \mathrm{R}$ in the lower gastrointestinal tract might be taken as support of the previous report [10] that $5-\mathrm{HT}_{3 \mathrm{~A}} \mathrm{R}$ contributes to motor function in the large intes- 


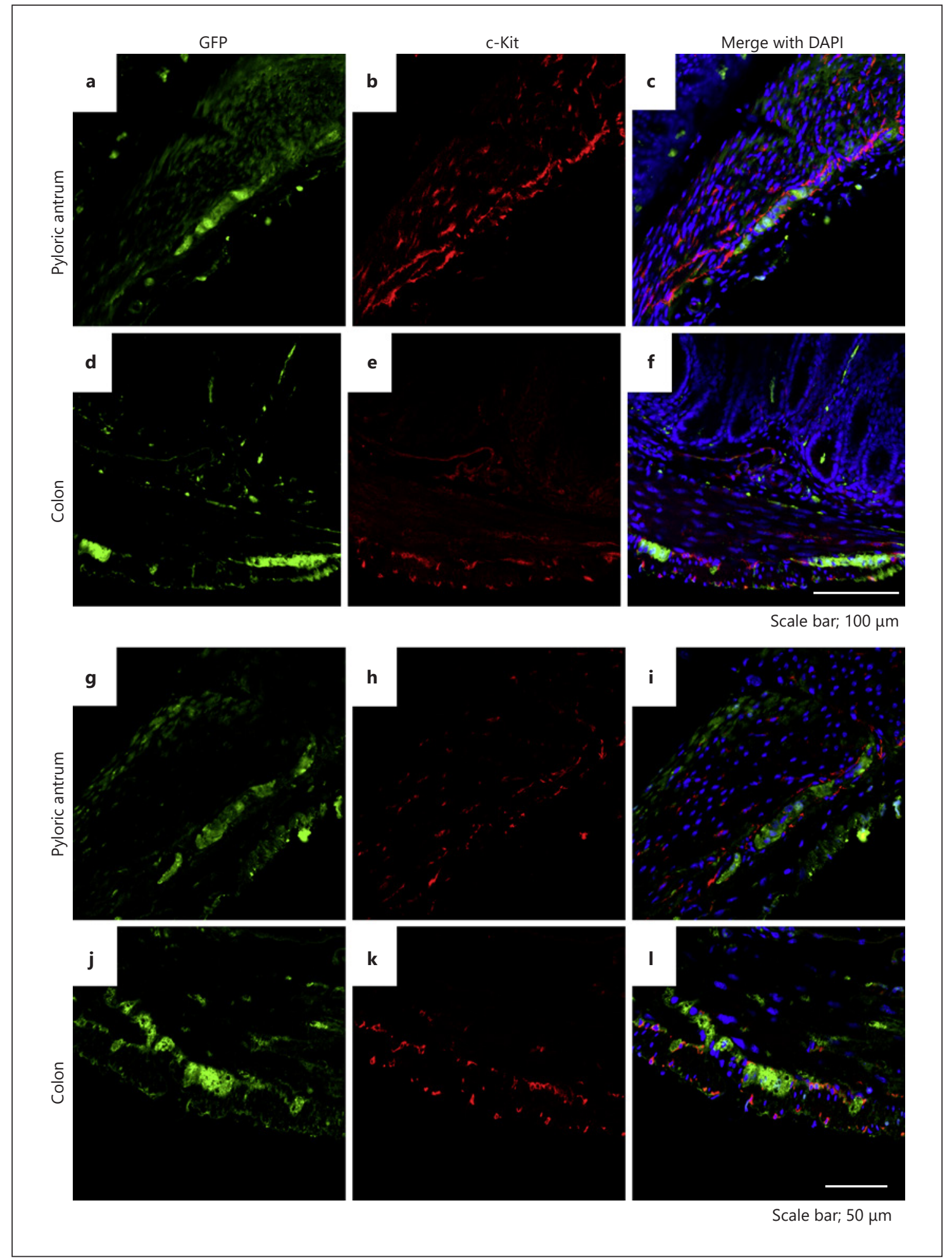

Fig. 5. Representative images of immunofluorescent staining for $5-\mathrm{HT}_{3 \mathrm{~A}} \mathrm{R}$ (green) and c-Kit (red) in the pyloric antrum $(\mathbf{a}-\mathbf{c}, \mathbf{g}-\mathbf{i})$ and colon $(\mathbf{d}-\mathbf{f}, \mathbf{j}-\mathbf{I})$ of $5-\mathrm{HT}_{3 \mathrm{~A}} \mathrm{R}$ GFP mice. Merged images are a combination of green and red color images. Scale bars, $100 \mu \mathrm{m}(\mathbf{a}-\mathbf{f}), 50 \mu \mathrm{m}(\mathbf{g}-\mathbf{I})$. 


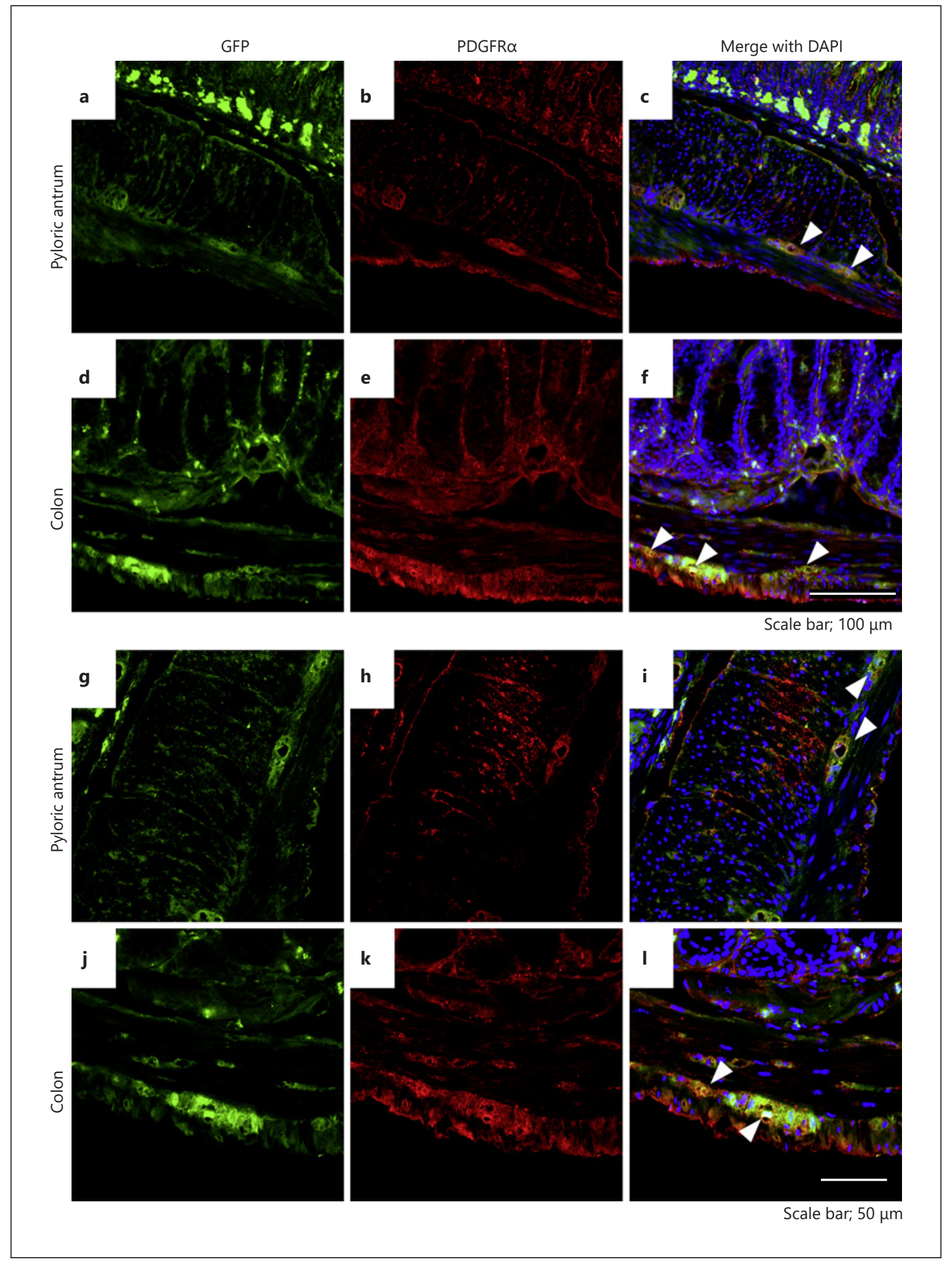

Fig. 6. Representative images of immunofluorescent staining for $5-\mathrm{HT}_{3 \mathrm{~A}} \mathrm{R}$ (green) and PDGFRa (red) in the pyloric antrum $(\mathbf{a}-\mathbf{c}, \mathbf{g}-\mathbf{i})$ and colon $(\mathbf{d}-\mathbf{f}, \mathbf{j}-\mathbf{I})$ of $5-\mathrm{HT}_{3 \mathrm{~A}} \mathrm{R}$ GFP mice. Merged images are a combination of green and red color images, which show cellular colocalization of GFP and PDGFRa. Arrowheads indicate merged cells (yellow). Scale bars, $100 \mu \mathrm{m}(\mathbf{a}-\mathbf{f}), 50 \mu \mathrm{m}(\mathbf{g}-\mathbf{I})$. 


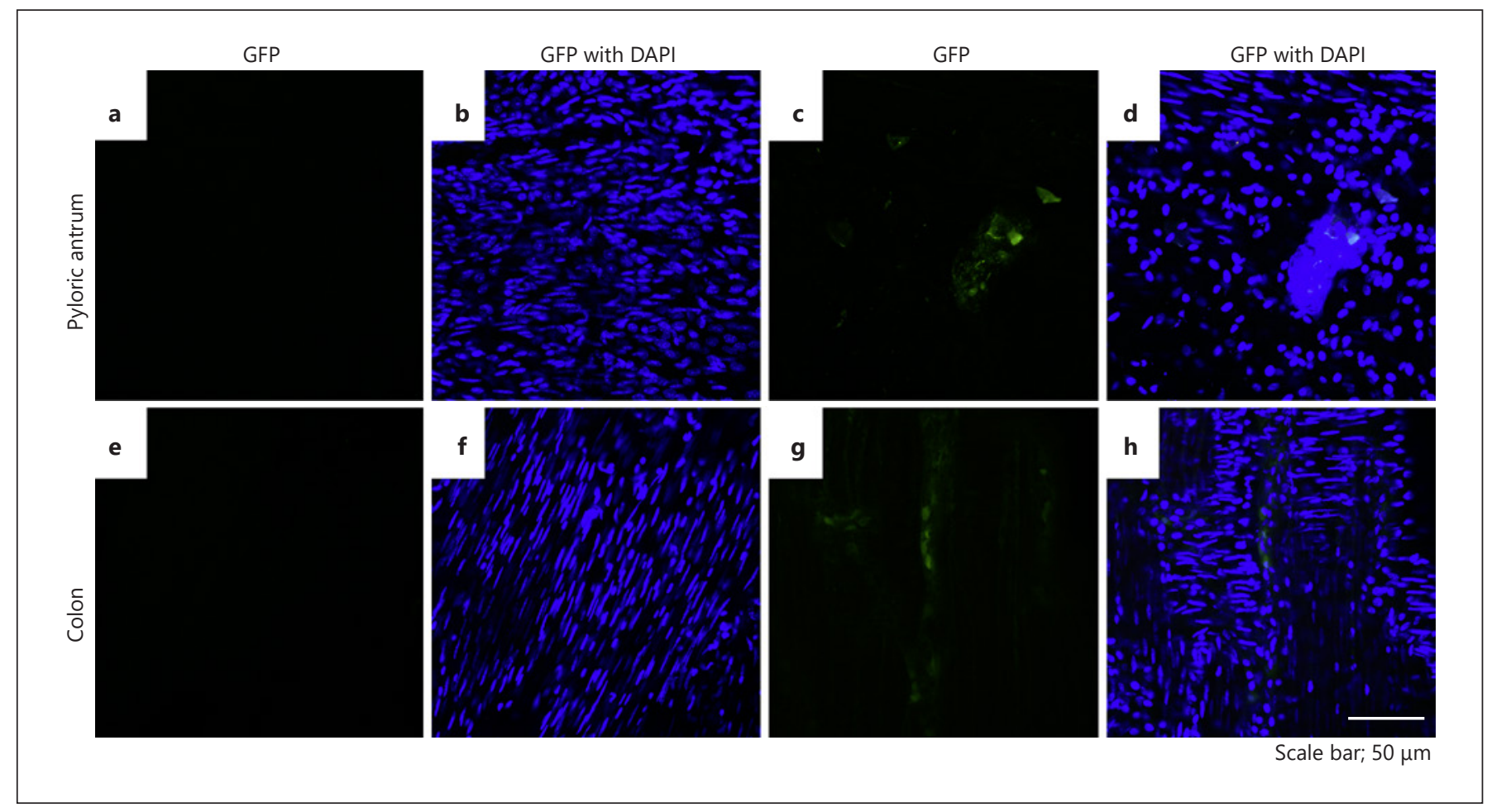

Fig. 7. Representative images of whole-mount samples for assessing GFP fluorescence (green) in the pyloric antrum $(\mathbf{a}-\mathbf{d})$ and colon $(\mathbf{e}-\mathbf{h})$ of WT mice $(\mathbf{a}, \mathbf{b}, \mathbf{e}, \mathbf{f})$ and $5-\mathrm{HT}_{3 \mathrm{~A}} \mathrm{R}$ GFP mice $(\mathbf{c}, \mathbf{d}, \mathbf{g}, \mathbf{h})$. DAPI (blue) indicates smooth muscle cells. Scale bars, $50 \mu \mathrm{m}(\mathbf{a}-\mathbf{h})$.

tine. Taken together, the findings indicate that it is possible that $5-\mathrm{HT}_{3 \mathrm{~A}} \mathrm{R}$ may be involved in motility, particularly in the stomach and large intestine. In support of our hypothesis, gastric emptying was significantly decreased in $5-\mathrm{HT}_{3 \mathrm{~A}} \mathrm{R} \mathrm{KO}$ mice. It has been reported that the administration of ondansetron, an inhibitor of $5-\mathrm{HT}_{3 \mathrm{~A}} \mathrm{R}$, has little effect on gastric emptying [22]. On the other hand, the inhibition of $5-\mathrm{HT}_{3 \mathrm{~A}} \mathrm{R}$ decreases smooth muscle movement, and gastric emptying is promoted by recovering the relaxation ability as a whole [23]. Thus, the hypothesis regarding the contribution of $5-\mathrm{HT}_{3 \mathrm{~A}} \mathrm{R}$ to gastric emptying has not been verified.

In this study, among the parameters used to evaluate the motility of the stomach, $T_{\max }$, which is the most suitable parameter for gastric emptying and is less affected by metabolism and excretion, was significantly increased in $\mathrm{KO}$ mice compared with WT mice, and it was suggested that gastric emptying in $\mathrm{KO}$ mice was delayed. However, a similar trend was observed for $T_{1 / 2}$, but no significant difference was found, and there were no differences in $C_{\max }$ and $\mathrm{AUC}_{240 \min }$ values between $\mathrm{WT}$ and $\mathrm{KO}$ mice. Thus, we concluded that a contribution of $5-\mathrm{HT}_{3 \mathrm{~A}} \mathrm{R}$ to gastric emptying may exist but relatively weak and limited.

There have been several reports of the contribution of 5-HT to colonic motility, but no certain knowledge has been obtained. For example, mice deficient in tryptophan hydroxylase 1 , which is involved in 5-HT biosynthesis, in enterochromaffin cells of the colonic mucosa do not show mucosal reflexes and exhibit a reduced response to intraluminal distension [24]. This suggests that $5-\mathrm{HT}$ is involved in motor function in the colon. On the other hand, it has been reported that peristalsis-like movement of the colon is induced even after mucosal removal [25] and treatment with reserpine, a 5-HT-depleting agent [26]. These studies show that $5-\mathrm{HT}_{3}$ receptor activation by endogenous 5-HT, or in fact the presence of any endogenous $5-\mathrm{HT}$, is not required for normal colonic transit in vivo [27], or in vitro [28-30]. However, how the $5-\mathrm{HT}_{3}$ receptor itself contributes to the excitability of the enteric nervous system is unclear. Therefore, we directly examined colonic motility by using $\mathrm{KO}$ mice.

In this study, the colon transit of $5-\mathrm{HT}_{3 \mathrm{~A}} \mathrm{R} \mathrm{KO}$ mice was significantly reduced compared with that in WT 
mice, and it was revealed that $5-\mathrm{HT}_{3 \mathrm{~A}} \mathrm{R}$ is involved in the control of colonic motility. In conclusion, these findings suggest that $5-\mathrm{HT}_{3 \mathrm{~A}} \mathrm{R}$ is at least partially involved in the motor function of the lower intestine.

This study focused on gastric emptying and colonic motility based on the results of gene expression analysis and clinical implications; however, there are many unsolved questions regarding the relationship between $5-\mathrm{HT}_{3 \mathrm{~A}} \mathrm{R}$ and small intestinal motility. In fact, pharmacological analysis has reported that $5-\mathrm{HT}_{3 \mathrm{~A}} \mathrm{R}$ is involved in the contraction of the small intestine in vitro, while some papers deny this in in vivo analysis $[31,32]$. Furthermore, $5-\mathrm{HT}_{4} \mathrm{R}$ is well known as a serotonin receptor involved in small intestinal motility; however, few studies have analyzed the expression level of $5-\mathrm{HT}_{4} \mathrm{R}$ in the small intestine. At least, the presence of $5-\mathrm{HT}_{4} \mathrm{R}$ has been identified in the submucosa and fascia of the guinea pig small intestine and may be strongly involved in motility regulation [33]. Further investigation using $5-\mathrm{HT}_{3 \mathrm{~A}} \mathrm{R} \mathrm{KO}$ and $5-\mathrm{HT}_{4} \mathrm{R} \mathrm{KO}$ mice is needed to conclusively demonstrate whether $5-\mathrm{HT}_{3 \mathrm{~A}} \mathrm{R}$ and $5-\mathrm{HT}_{4} \mathrm{R}$ are involved in small intestinal motility.

In recent years, it has been proposed that the motor function of the digestive tract is regulated by a structure known as the SIP syncytium, composed of smooth muscle cells, ICC, and PDGFRa ${ }^{+}$cells [13], indicating that it is necessary to examine $5-\mathrm{HT}_{3 \mathrm{~A}} \mathrm{R}$-expressing cells in the myenteric plexus, including the SIP syncytium. Attempts have been made to identify $5-\mathrm{HT}_{3 \mathrm{~A}} \mathrm{R}$-expressing cells using $5-\mathrm{HT}_{3 \mathrm{~A}} \mathrm{R}$ antibodies. Cholinergic nerves have been confirmed to express $5-\mathrm{HT}_{3 \mathrm{~A}} \mathrm{R}$ via immunohistochemical staining [17]. On the other hand, the transcriptome analysis database indicates that $5-\mathrm{HT}_{3 \mathrm{~A}} \mathrm{R}$ is expressed in PDGFRa $^{+}$cells at the mRNA level [34], but its expression has not been confirmed at the protein level. In this study, immunohistochemical staining revealed that $5-\mathrm{HT}_{3 \mathrm{~A}} \mathrm{R}$ was expressed in cholinergic neurons and PDGFRa ${ }^{+}$cells. These findings suggest the possibility that $5-\mathrm{HT}_{3 \mathrm{~A}} \mathrm{R}$ may regulate gastrointestinal motility not only through cholinergic excitatory nerves but also through PDGFRa ${ }^{+}$cells that regulate inhibitory neurosignaling. Further detailed examination will be necessary to clarify this point.

However, in this study, $5-\mathrm{HT}_{3 \mathrm{~A}} \mathrm{R}$ labeled with GFP fluorescence was rarely detected in ICC. This finding did not agree with the results obtained for $5-\mathrm{HT}_{3 \mathrm{~A}} \mathrm{R}$ expression at the mRNA level in ICC reported in the aforementioned database and previous studies [16, 34]. Recently, it was reported that the pacemaker function of ICC is enhanced by the activation of $5-\mathrm{HT}_{3 \mathrm{~A}} \mathrm{R}$ [16].

The GFP reporter mice used in the present study are transgenic mice in which the $5-\mathrm{HT}_{3 \mathrm{~A}} \mathrm{R}$ promoter is up- stream of GFP, so the 5- $\mathrm{HT}_{3 \mathrm{~A}} \mathrm{R}$ gene remains homozygous and normal. Therefore, the function and expression levels of $5-\mathrm{HT}_{3 \mathrm{~A}} \mathrm{R}$ are not affected by GFP insertion. This discrepancy may therefore indicate a possible difference between the gene level and protein level of $5-\mathrm{HT}_{3 \mathrm{~A}} \mathrm{R}$. According to the above, it is thought that further verification of the difference between the analysis results using the reporter mouse and the functional analysis methods and antibodies reported thus far is necessary.

Similarly, in smooth muscle cells, expression at the mRNA level of $5-\mathrm{HT}_{3 \mathrm{~A}} \mathrm{R}$ was confirmed in the aforementioned database [34], and hyperpolarization related to the colonic migrating motor complex was blocked via ondansetron administration in the colon from which the mucosa was removed [35]. These reports do not support our results; however, the reason for this disparity may be the same as the reason for the discrepancy in ICC. Additional physiological studies will be required to conclusively correlate $5-\mathrm{HT}_{3 \mathrm{~A}} \mathrm{R}$ with ICC function, such as electrophysiological measurement of pacemaker potential in ICC.

In conclusion, these results suggest that $5-\mathrm{HT}_{3 \mathrm{~A}} \mathrm{R}$ is highly expressed in the stomach and lower gastrointestinal tract and that $5-\mathrm{HT}_{3 \mathrm{~A}} \mathrm{R}$ activation at least increases gastric emptying and colon transit. In addition, immunohistochemical analysis using reporter mice showed that $5-\mathrm{HT}_{3 \mathrm{~A}} \mathrm{R}$ may be expressed not only in cholinergic neurons but also in some interstitial cells, such as PDGFR $\alpha^{+}$cells.

\section{Acknowledgements}

We would like to thank American Journal Experts (www.aje. com) for English language editing.

\section{Statement of Ethics}

All of the animal care and experimental procedures complied with the Guide for Animal Use and Care published by The University of Tokyo and were approved by the Institutional Review Board of The University of Tokyo (P17-091).

\section{Conflict of Interest Statement}

The authors have no conflicting interests to declare.

\section{Funding Sources}

This work was supported by a Grant-in-aid for Scientific Research from The Ministry of Education, Culture, Sports, Science and Technology $(24248050,25221205$, and $19 H 03125$ to M.H. and 18 K14604 and 19H03558 to N.K.). 


\section{Author Contributions}

S.A. and K.K.: designed and performed the experiment, analyzed the data, interpreted the results, and wrote the manuscript.
N.K. and S.M.: provided technical support and critical comments on the manuscript. M.K. and S.S.: provided the animals and critical comments on the manuscript. M.H.: supervised the project and revised the manuscript.

\section{References}

1 Gershon MD, Tack J. The serotonin signaling system: from basic understanding to drug development for functional GI disorders. Gastroenterology. 2007 Jan;132(1):397-414

2 Walther DJ, Peter JU, Winter S, H“oltje M, Paulmann N, Grohmann M, et al. Serotonylation of small GTPases is a signal transduction pathway that triggers platelet alpha-granule release. Cell. 2003;115(7):851-62.

3 Margolis KG, Stevanovic K, Li Z, Yang QM, Oravecz T, Zambrowicz B, et al. Pharmacological reduction of mucosal but not neuronal serotonin opposes inflammation in mouse intestine. Gut. 2014;63(6):928-37.

4 Erspamer V. Pharmacology of indole-alkylamines. Pharmacol Rev. 1954;6(4):425-87.

5 Sanger GJ. 5-hydroxytryptamine and the gastrointestinal tract: where next? Trends Pharmacol Sci. 2008 Sep;29(9):465-71.

6 Derkach V, Surprenant A, North RA. 5-HT3 receptors are membrane ion channels. $\mathrm{Na}-$ ture. 1989 Jun 29;339(6227):706-9.

7 Jackson MB, Yakel JL. The 5-HT3 receptor channel. Annu Rev Physiol. 1995;57:447-68.

8 Koyama Y, Kondo M, Shimada S. Building a 5-HT3A receptor expression map in the mouse brain. Sci Rep. 2017 Mar 9;7:42884.

9 Tyers MB, Freeman AJ. Mechanism of the anti-emetic activity of 5-HT3 receptor antagonists. Oncology. 1992;49(4):263-8.

10 Pascual D, Alsasua A, Goicoechea C, Martín MI. The involvement of 5-HT3 and 5-HT4 receptors in two models of gastrointestinal transit in mice. Neurosci Lett. 2002 Jul 5;326(3): 163-6.

11 Grundy D, Blackshaw LA, Hillsley K. Role of 5-hydroxytryptamine in gastrointestinal chemosensitivity. Dig Dis Sci. 1994 Dec;39(12 Suppl):44S-7S.

12 Lindley C, Blower P. Oral serotonin type 3-receptor antagonists for prevention of chemotherapy-induced emesis. Am J Health Syst Pharm. 2000 Sep 15;57(18):1685-97.

13 Kurahashi M, Mutafova-Yambolieva V, Koh SD, Sanders KM. Platelet-derived growth factor receptor- $\alpha$-positive cells and not smooth muscle cells mediate purinergic hyperpolarization in murine colonic muscles. Am J Physiol Cell Physiol. 2014 Sep 15;307(6): C561-70.

14 Sakurai-Yamashita Y, Yamashita K, Kaibara M, Enjoji A, Kanematsu T, Taniyama K. Differential distribution of 5-hydroxytryptamine3 receptor in the colon between human and guinea pig. Chin J Physiol. 1999 Sep 30; 42(3):195-8.

15 Sakurai-Yamashita Y, Yamashita K, Yoshimura M, Taniyama K. Differential local- ization of 5-hydroxytryptamine 3 and 5-hydroxytryptamine 4 receptors in the human rectum. Life Sci. 2000;66(1):31-4.

16 Liu HN, Ohya S, Nishizawa Y, Sawamura K, Iino S, Syed MM, et al. Serotonin augments gut pacemaker activity via 5 -HT3 receptors. PLoS One. 2011;6(9):e24928.

17 Glatzle J, Sternini C, Robin C, Zittel TT, Wong $\mathrm{H}$, Reeve JR Jr, et al. Expression of 5-HT3 receptors in the rat gastrointestinal tract. Gastroenterology. 2002 Jul;123(1):217-26.

18 Bush TG, Spencer N. Watters N, Sanders KM, Smith TK. Effects of alosetron on spontaneous migrating motor complexes in the murine small and large intestine. Am J Physiol Gastrointest Liver Physiol. 2001 Oct;281(4): G974-83.

19 Li Z, Chalazonitis A, Huang YY, Mann JJ, Margolis KG, Yang QM, et al. Essential roles of enteric neuronal serotonin in gastrointestinal motility and the development/survival of enteric dopaminergic neurons. J Neurosci. 2011 Jun 15;31(24):8998-9009.

20 Kishi K, Kaji N, Endo M, Tsuru Y, Oikawa T, Hori M. Development of a quantitative method for evaluating small intestinal motility using ultrasonography in mice. Exp Anim. 2019 Aug 14;68(3):381-9.

21 Bellono NW, Bayrer JR, Leitch DB, Castro J, Zhang C, O'Donnell TA, et al. Enterochromaffin cells are gut chemosensors that couple to sensory neural pathways. Cell. 2017 Jun 29; 170(1):185-98.e16.

22 Savoye G, Brung-Lefebvre M, Bouin M, Maillot C, Denis P, Ducrotté P. Effects of ondansetron on gastric tone and motility changes induced by a prolonged intraduodenal infusion of nutrients. Results of a placebo-controlled study. Dig Dis Sci. 2007 Oct;52(10): 2676-83.

23 Tominaga K, Kido T, Ochi M, Sadakane C, Mase A, Okazaki H, et al. The traditional Japanese medicine Rikkunshito promotes gastric emptying via the antagonistic action of the 5 -HT(3) receptor pathway in rats. Evid Based Complement Alternat Med. 2011;2011: 248481.

24 Heredia DJ, Gershon MD, Koh SD, Corrigan RD, Okamoto T, Smith TK. Important role of mucosal serotonin in colonic propulsion and peristaltic reflexes: in vitro analyses in mice lacking tryptophan hydroxylase 1. J Physiol. 2013 Dec 1;591(23):5939-57.

25 Keating DJ, Spencer NJ. Release of 5-hydroxytryptamine from the mucosa is not required for the generation or propagation of colonic migrating motor complexes. Gastroenterology. 2010 Feb;138(2):659-70.
26 Sia TC, Flack N, Robinson L, Kyloh M, Nicholas SJ, Brookes SJ, et al. Is serotonin in enteric nerves required for distension-evoked peristalsis and propulsion of content in guinea-pig distal colon? Neuroscience. 2013 Jun 14;240:325-35.

27 Yadav VK, Balaji S, Suresh PS, Liu XS, Lu X, $\mathrm{Li} Z$, et al. Pharmacological inhibition of gutderived serotonin synthesis is a potential bone anabolic treatment for osteoporosis. Nat Med. 2010 Mar;16(3):308-12.

28 Spencer NJ, Nicholas SJ, Robinson L, Kyloh M, Flack N, Brookes SJ, et al. Mechanisms underlying distension-evoked peristalsis in guinea pig distal colon: is there a role for enterochromaffin cells? Am J Physiol Gastrointest Liver Physiol. 2011 Sep;301(3):G519-27.

29 Spencer NJ, Keating DJ. Is there a role for endogenous 5-HT in gastrointestinal motility? How recent studies have changed our understanding. Adv Exp Med Biol. 2016;891:11322.

30 Vincent AD, Wang XY, Parsons SP, Khan WI, Huizinga JD. Abnormal absorptive colonic motor activity in germ-free mice is rectified by butyrate, an effect possibly mediated by mucosal serotonin. Am J Physiol Gastrointest Liver Physiol. 2018 Nov 1;315(5):G896-G907.

31 Clayton NM, Sargent R, Butler A, Gale J, Maxwell MP, Hunt AA, et al. The pharmacological properties of the novel selective 5-HT3 receptor antagonist, alosetron, and its effects on normal and perturbed small intestinal transit in the fasted rat. Neurogastroenterol Motil. 1999 Jun;11(3):207-17.

32 Talley NJ, Phillips SF, Haddad A, Miller LJ, Twomey C, Zinsmeister AR, et al. Effect of selective 5HT3 antagonist (GR 38032F) on small intestinal transit and release of gastrointestinal peptides. Dig Dis Sci. 1989 Oct; 34(10):1511-5.

33 Pan H, Gershon MD. Activation of intrinsic afferent pathways in submucosal ganglia of the guinea pig small intestine. J Neurosci. 2000 May 1;20(9):3295-309.

34 Breland A, Ha SE, Jorgensen BG, Jin B, Gardner TA, Sanders KM, et al. Smooth Muscle Transcriptome Browser: offering genomewide references and expression profiles of transcripts expressed in intestinal SMC, ICC, and PDGFRa+ cells. Sci Rep. 2019 Jan 23; 9(1):387.

35 EJ Dickson, DJ Heredia, and TK Smith . Critical role of 5-HT1A, 5-HT3, and 5-HT7 receptor subtypes in the initiation, generation, and propagation of the murine colonic migrating motor complex. Am J Physiol Gastrointest Liver Physiol. 2010;299:G144-57. 